\title{
EAMR
}

European Accounting and

Management Review

EUROPEAN ACCOUNTING AND MANAGEMENT REVIEW · VOL. 3, NO. 2, 45-64 MAY 2017

\section{Managing sporting success and economic efficiency in the professional football: Identification of determinant factors through the academic literature}

\author{
Nicole Kalemba \\ Universitat Rovira i Virgili-Business Management \\ Fernando Campa \\ Universitat Rovira i Virgili - Business Management
}

Received April 10, 2017; accepted May 22, 2017.

\begin{abstract}
Football moves crowds, both fans and millions of euros. Football clubs are not any longer just sport teams that focus on winning competitions, but they have turned into complex business units with a high economic and social impact.

The main purpose of this study is to conduct a review on the existing international academic literature for providing an insight into the management of sporting success and economic efficiency in the international professional football industry.

Findings show that sporting success is influenced, on one hand, by human capital and positive results on an international competition level and, on the other hand by the financial support through sport organizations' related attributes and investments.

Further, sporting success creates economic efficiency leading consequently to a higher profitability of football organizations.

This paper can be helpful for managers, practitioners as well as academics, as currently does not exist any literature review on this topic.
\end{abstract}

\section{KEYWORDS}

Football, management, profitability, economic efficiency, sporting success, capital structure. 


\section{Introduction}

Sport is one of the most diverse business industries in the world, having a massive global effect (Parks and Quarterman, 2003; Gásquez and Royuela, 2016). It has been practically an integral part of mankind since the founding of the first social organizations (Sportcal, 2016), being considered as a productive sector with multidisciplinary characteristics that has become a complex phenomenon influencing the society due to its enormous dimensions and heterogeneity (AEA, 2002).

The constant increase of sports popularity as well as its growing relevance have created an industry of a scale of enormous monetary amounts and huge impact on the world's economy (Yasar et al., 2015; Sportcal, 2016). Together with the interest that sport generates in the fans, attracting millions of people all over the world (KPMG Sports, 2015), sport has turned into a business of large dimensions (Fort, 2003; Calzada, 2012). The sport industry stands out from other industries since firms, consisting generally in teams, want to maximize their profit, "serving a demand for their product in their output market" (Stewart and Jones, 2010; Weinberg, 2016), offering two outputs, namely performance and entertainment.

Many sports have been characterized in recent years by an increasing professionalization and commercialization. Especially in Europe, this fact is applied to the football ${ }^{1}$ industry and the belonging professional leagues (Wulf and Hungenberg, 2006, Calzada, 2012). Those started changing their business models, putting their focus on adapting gradually to the customer's needs (KPMG Sports, 2015) and shifting from considering in many cases economic more than sporting competition.

Sixty years ago, football was just a "national affair", where the main competition form was based on the domestic league and any international competition was still a small matter (Szymanski, 2006). Since the 1990s, football has gone through a period of economic growth, having faced different economic crisis (Bács, 2014).

There is no doubt that football is nowadays a globally practiced sport and in terms of number of sport fans. Figure 1 shows the importance and status that football attains towards other kinds of sports, being with 1.6 billion of persons in 2015 the most followed sport (Statista, 2015).

\footnotetext{
${ }^{1}$ Soccer in the US
} 


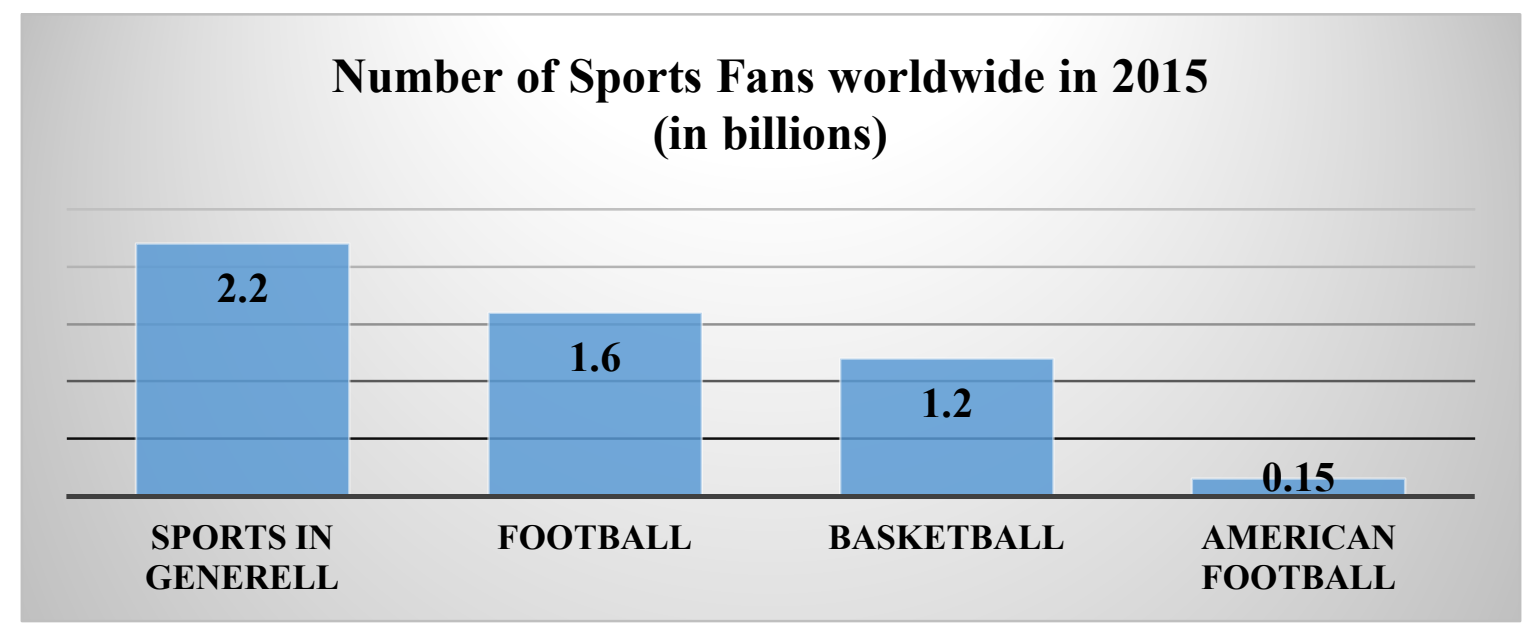

Figure 1. Number of Sports Fans worldwide 2015 (Author's own work based on data of Statista, 2015)

On one hand, no sport activates so many spectators and fans as football does. On the other hand, no sport produces, on a professional level, such a broad and relevant turnover through the populations' interest.

The importance of football enthusiasm and its enormous far-reaching consequences in today's societies is undisputedly, being a global phenomenon with diverse economic as well as social dimensions (AEA, 2002). Compared to other sport disciplines, the economic strength of football has been a long-accepted part of the society.

Economically, football is a product that customers consume attending matches or following the media and somehow it is the associations, clubs, the sports equipment industry as well as media that are producing football (Stewart and Jones, 2010; BMWi and BISp, 2015).

The football industry creates employment and contributes positively and significantly to the country's Gross Domestic Product (GDP), as well as it provokes indirect impacts as for instance the creation of jobs related to sectors as hospitality, leisure, construction companies, between others (KPMG Sports, 2015).

Additionally, football creates, far beyond the economic impact, also social benefits, as follows (Parks and Quarterman, 2003; Commission of the European Communities, 2007; KPMG Sports, 2015; BMWi and BISp, 2015; Gásquez and Royuela, 2016): 
- Positive impact of sporting success generates admiration, recognition and affection and encourages young people

- Creates identity and makes people feeling like belonging to a group; thus, it contributes to the socialization process

- Improves personal values and skills and contributes to the role learning

- Promotes the ability of teamwork and respect to the opponents

- Helps to manage and understand both success and failure

- Contributes to the public health improvement

It is clear, that football is not any longer just a sport that is focused on the sporting success, but rather it has turned into a business with a high economic impact and a significant contribution to the GDP (KPMG Sports, 2015). Football clubs are nowadays much more than being just a simple sport organization, as they have turned into complex business units (Pyatunin et al., 2016; Bács, 2014; Guzmán and Morrow, 2007). The organizational structure of sport clubs differentiates from the traditional business management due the wide range of activities that have to be added to the core activity, as for instance facilities, stadiums, supporters' related factors (merchandising and ticketing), commercial activities and media related attributes, between others (Yasar et al., 2015; KPMG Sports, 2015).

Considering the sporting performance of the international top teams, figure 2 shows the UEFA ranking of the top 5 clubs' coefficients by federations for the seasons 2012/2013 to $2016 / 2017$ which is based on the results of the clubs of each federation for the last five years of competition. The ranking considers both the UEFA Europa League and the UEFA Champions League (UEFA, 2017).

Except in 2012/2013, Spain has been the leading federation for the last four consecutive seasons as a result of the positive sporting performance of clubs as Real Madrid CF, FC Barcelona, Club Atlético de Madrid and Sevilla FC.

While Real Madrid CF won the UEFA Champions league in the seasons 2013/2014 and 2015/2016, FC Barcelona got the trophy in 2014/2015. On the other hand, Sevilla FC won the UEFA Europa League during three consecutive years, from 2013/2014 to $2015 / 2016$ 


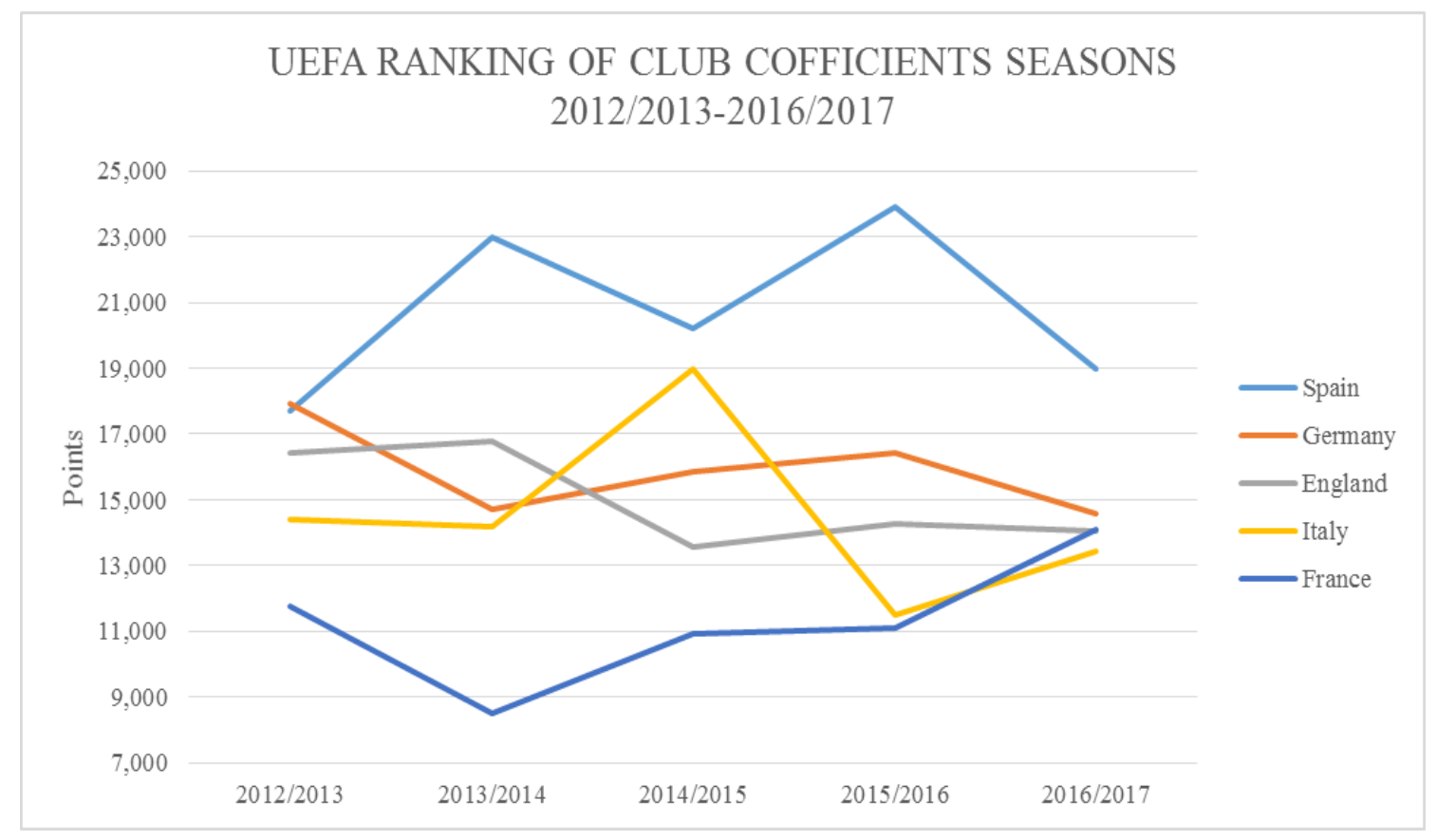

Figure 2. UEFA Ranking of club coefficients seasons 2012/2013-2016-2017 (Author's own work based on data UEFA, 2017)

Therefore, the interest of this paper lies first in giving an overview on the Spanish professional football league and second, in identifying through a review of existing academic literature, how sporting success and economic efficiency interact nowadays in the professional football industry, as well as to see which attributes play a significant intermediary role.

The paper is structured as follows. After an introduction, initially, it offers a general overview on the evolution of Spanish football, showing the evolution of expenses and income of the Spanish professional football league (LFP), as well as the impact that football has on the Spanish GDP. Thereafter, it is described the existing academic literature in relation to the research topic. The last section presents the conclusions drawn from this study. 


\section{Football in Spain: development and evolution}

Considering professional football in Spain it is necessary to include both; the First division (currently named LaLiga Santander); as well as the second division A (currently named LaLiga 1/2/3).

As mentioned previously, Spain is the leading federation in the UEFA ranking of club coefficients during the last four years. Therefore, this section will give an overview on the development and evolution of the main professional football league in Europe, Spain, considering its economic and financial situation.

\section{Income and expenses}

Figures 3 and 4 indicate the evolution of the income and expenses generated during the seasons $1999 / 2000$ to $2015 / 2016$, where both the first division and second division A have been included separately.

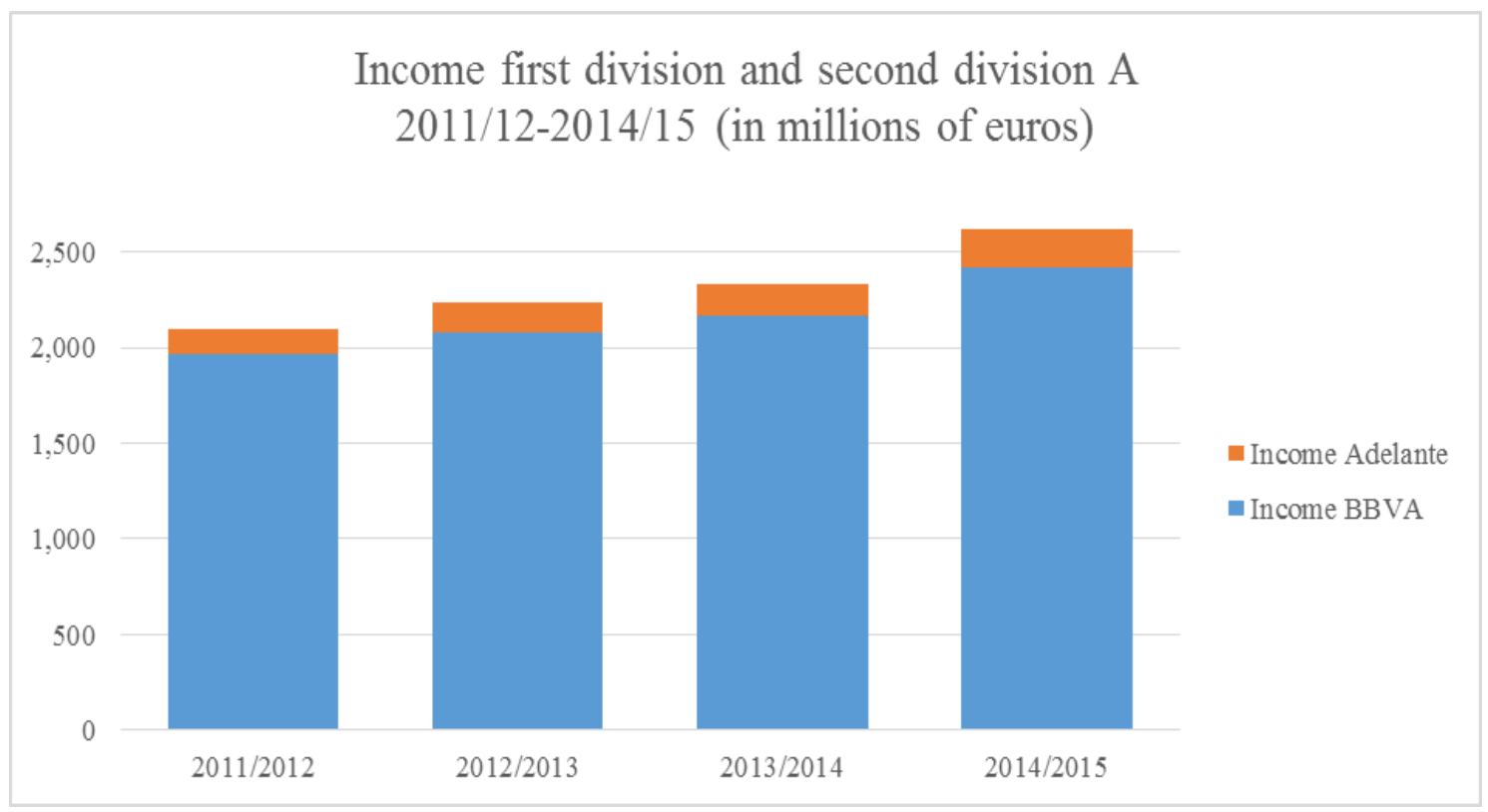

Figure 3. Income first division and second division A 2011/2012-2014/2015 (Author's own work based on data of LaLiga, 2015)

Figure 3 shows that the income of the Spanish professional football league is having a continuous growth and stability with an interannual growth rate of a $24.7 \%$ between the seasons 2011/2012 and 2014/2015, reaching a total amount 2,615.60 million of euros in $2014 / 2015$. 
The second division A and first division generated an amount of 198.4 million of euros and 2,417.20 million of euros, respectively.

The main are coming from broadcast rights, tickets sales, marketing, advertising, and players' transfers. Broadcast is with more than $30 \%$ the largest contributor of income in the Spanish professional football industry, having also a high impact on the Europe's premier leagues (Deloitte, 2016), followed by the income generated through the match day and marketing (LaLiga, 2015).

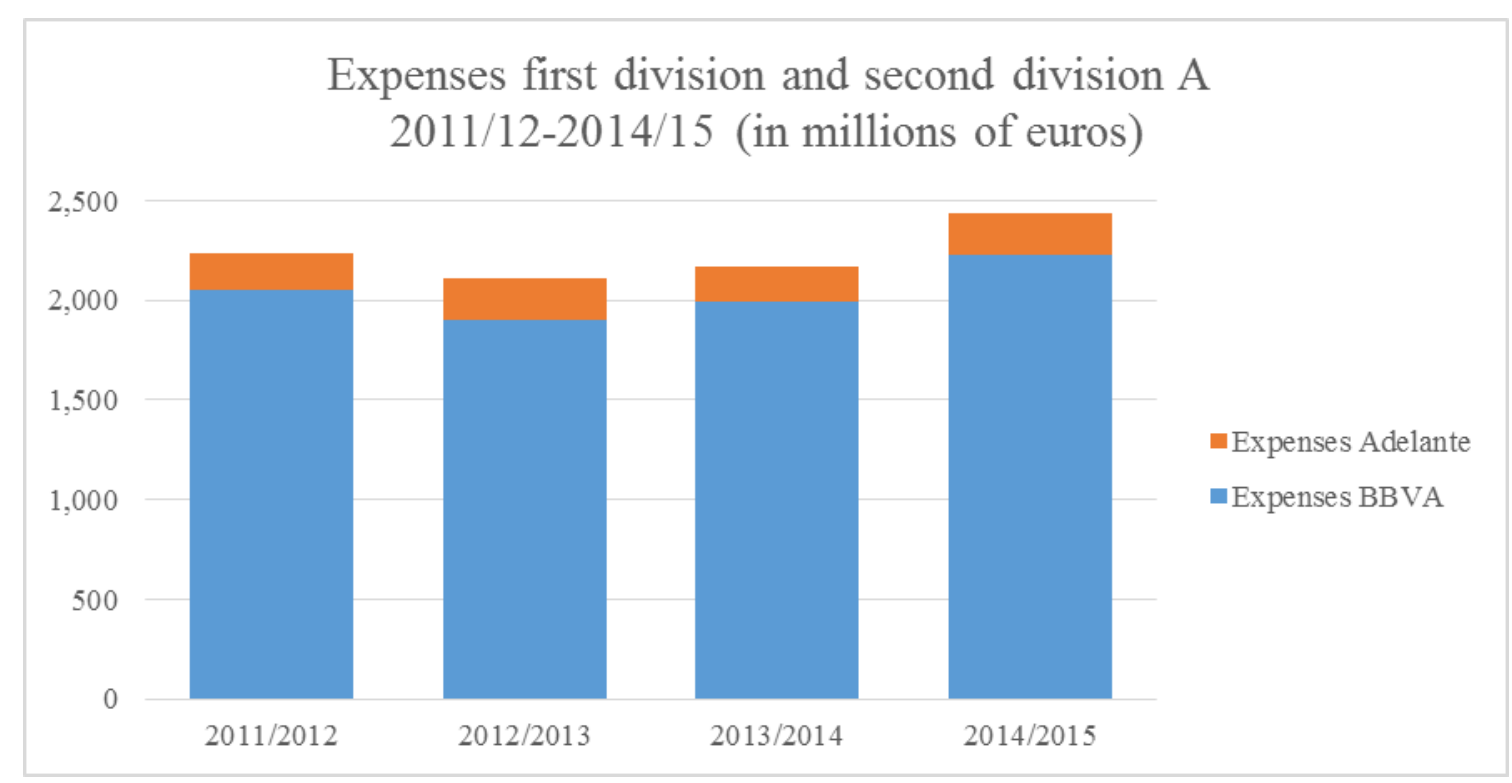

Figure 4. Expenses first division and second division A 2011/2012-2014/2015 (Author's own work based on data of LaLiga, 2015)

In relation with the expenses generated through the Spanish professional football, they show a slight increase during the seasons 2012/2013 to 2014/2015. The expenses are primarily made up of players and staff costs with the highest share of expenses $(>50 \%)$, as well as transfers, procurement, amortizations, and financial expenses.

Considering the difference between income and expenses a positive evolution is given, as table 1 shows, reaching in 2014/2015 a profit of 183.4 million of euros, fact that allows the reduction of debts, strengthening the financial assets. 


\begin{tabular}{|l|c|c|c|c|}
\hline In millions of $€$ & $\mathbf{2 0 1 1} / \mathbf{2 0 1 2}$ & $\mathbf{2 0 1 2 / 2 0 1 3}$ & $\mathbf{2 0 1 3} / \mathbf{2 0 1 4}$ & $\mathbf{2 0 1 4 / 2 0 1 5}$ \\
\hline Income & $2,097.0$ & $2,235.8$ & $2,328.1$ & $2,615.6$ \\
\hline Expenses & $2,232.3$ & $2,111.4$ & $2,172.0$ & $2,432.2$ \\
\hline Difference & -135.3 & 124.4 & 156.1 & 183.4 \\
\hline
\end{tabular}

Table 1. Difference between Income and Expenses of the Spanish professional football in millions of euros during the seasons 2011/2012-2014/2015 (Author's own work based on data of LaLiga, 2015)

\section{Contribution to the Spanish GDP}

Another evidence that demonstrates the importance that football has, is the contribution and the direct and indirect impact of the professional football to the Spanish GDP (KPMG, 2015). The impact on the Spanish GDP has grown slightly during the last years, contributing nowadays almost a $1 \%$, generating yearly about 8 billion euros (KPMG Sports, 2015; LaLiga, 2015).

The direct impact is related to the employment that football generates, considering media, supporters, advertising, sponsors, transportation sectors, the hospitality sector, between others. Moreover, the indirect impact on the GDP is referred to cultural, leisure and sporting activities (KMPG, 2015). 


\section{Methodology}

It has been carried out a literature review mainly through two relevant academic bibliographic databases, Web of Science (2017) and Scopus (2017), being both tools for identifying core papers related to the research topic. Further, it has been included also non-academic documents that give an added value to the research.

\section{Identification of academic literature}

For the identification of the factors that determine the relationship between sporting success and economic efficiency, several keywords that are based on the authors' opinions, have been used with different combinations between each of them.

These keywords, included in figure 5, are as follows:

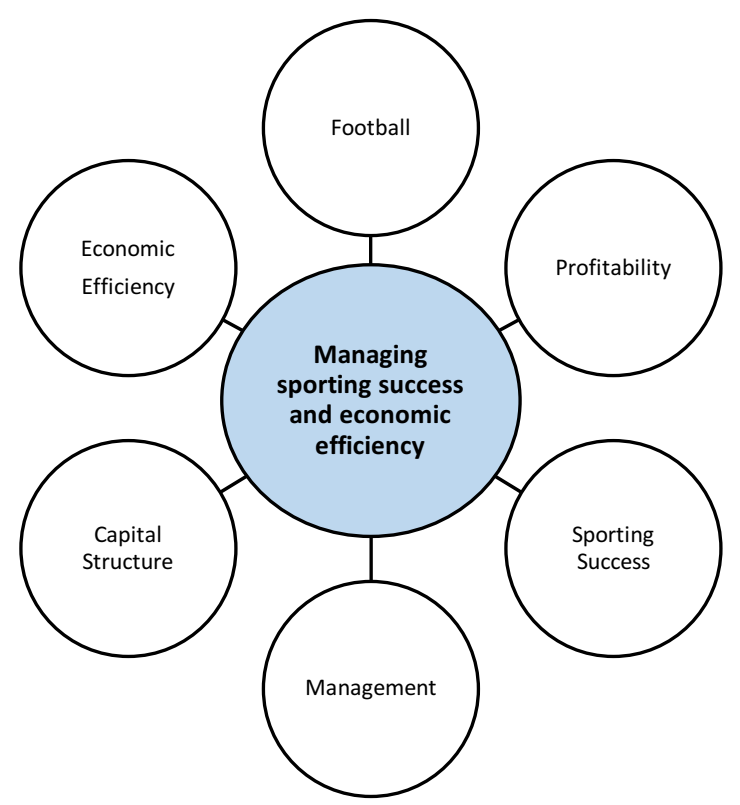

Figure 5. Keywords used for the literature review

\section{Sample of papers and documents}

The final sample selection of papers has been a total of 15 papers, being all of them related to the professional and international football industry. 13 of those papers were found in the database Scopus (2017), meanwhile 4 of them were included in the database Web of Science (2017), therefore two of the academic papers coincided in both databases. The period of papers' publications found is from 2004 to 2017. 


\section{Literature review}

Due to the increasing importance of football as a business unit, this section intends to show the attributes that have to be considered in case of the international professional football industry and how those interact between each other. It has been carried out, as previously mentioned, a literature review that allows us obtaining academic publications and documents for getting a previous conclusion about the research topic.

As seen in figure 7, the clubs should distinguish between two main objectives that should be achieved. First, sporting success and second, economic efficiency. But the question is, which are the prerequisites that should be considered both for sporting success and economic efficiency?

Several authors have treated the management of or sporting football success (Guzmán and Morrow, 2007; Gásquez and Royuela, 2016; Pyatunin et al., 2016; Carmichael et al., 2017; Magaz-González et al., 2017), or the economic efficiency of football teams (Espitia-Escuer and García-Cebrián, 2010; Goddard and Sloane, 2014; Pyatunin et al., 2016).

\section{Efficiency}

According to the literature (Espitia-Escuer and García-Cebrián, 2004; 2010 and 2014), efficiency consists in a frugal use of available resources, thus, accomplishing activities during the sporting competition in an opportune way. Efficiency relates both inputs (means) and outputs (ends) (Guzmán and Morrow, 2007); and is seen as an essential factor in any organization (Espitia-Escuer and García-Cebrián, 2010), where efficiency is considered as the final criteria of determining the performance of a company. In the case of football clubs the main purpose for achieving efficiency is to have a good final position in their competitions.

\section{Sporting success}

Initially, one of the main objectives of a football club or an organization is it to get the best possible outcome as a team measured through obtained league points. Sporting success is the combination of inputs, both player and non-player related (Carmichael et al., 2017).

To achieve sporting success, it is necessary to take into account several attributes. 
As seen in figure 7 and based on the reviewed literature, one of the main elements for a positive sporting outcome is the human capital (Yasar et al., 2015), being the core of intellectual capital and the sum of elements as talent, experience, knowledge, team harmony and success of players and coaches. This, in turn, leads to the motivation of customer engagement and affects the market value of the club.

According to the literature reviewed, human capital can be divided into three parts.

Firstly, the team, where personality characteristics as skills and talent, experience average, form, fitness, age and culture should be included (Espitia-Escuer and GarcíaCebrián, 2004; Wulf and Hungenberg, 2006; Yasar et al., 2015; Carmichael et al., 2017), as well as the fact of having young local club players. One of the best examples is the FC Barcelona (Murillo, 2012), club that persists in a business-related sporting model based on the talent and the training of own young local players.

The better the players and the more skilled and talented they are, and the more experience they have, higher will be the possibility of the teams' sporting success (Magaz-González et al., 2017).

Secondly, the coach, where the sporting success is primarily related with personality characteristics as experience, term of office and the age (Wulf and Hungenberg, 2006; Carmichael et al., 2017). Especially experience plays an important role, as more knowledgeable and qualified the coaches much better they can deal with the high pressure throughout the season. In addition, they have already some awareness about the way of playing of their opponents from previous encounters and therefore, they can more easily adapt to and anticipate situations adequately. (Wulf and Hungenberg, 2006).

Another point that should be considered when talking about the coach as human capital, is the technical efficiency, that is, the ability to get the best out of the players with a satisfactory team strategy (Prestana Barros et al., 2009; Espitia-Escuer and GarcíaCebrián, 2014; Jara et al., 2015).

Lastly, the club management, considering as necessary success determinant characteristics the professional training of managers and their term of office for reaching sporting success (Espitia-Escuer and García-Cebrián, 2004; Wulf and Hungenberg, 2006; Yasir et al., 2015). 
Additionally, from having divided the human capital in three parts and seeing the factors that influence a favorable sporting outcome, it is essential to contemplate two different points of view about sporting success. First, on-field success that is primarily influenced by the team and the coach (Guzmán and Morrow, 2007; Espitia-Escuer and GarcíaCebrián, 2010; Carmichael et al., 2017), while off-field success depends mainly on the club management and in small part on the coach (Guzmán and Morrow, 2007).

Another attribute that contributes to the sporting success of a football team, is the participation in the strongest international competitions, as for instance the UEFA Champions League, UEFA Europa League and/or, on the other hand, the own domestic cup on a national level. The achievement of victories and trophies, but also the achievement of positive results during the season, both in the national league and also reaching the knockout phase of international competition, for instance, is without doubt an important, essential and determinant factor of sporting success (Pyatunin et al., 2016).

\section{Financial efficiency and support}

Sporting success is also a driver of financial success (Rohde and Breuer, 2016) and highly related with the financial efficiency of clubs, being a prerequisite for making profit and achieving, in turn, economic efficiency. (Pyatunin et al., 2016).

As figure 7 shows, the financial support comes also from sport organizations' related terms as media, sponsors and supporters (Calzada, 2012; Bács, 2014; Mullin et al., 2014; Szymanski, 2014). In this way, revenues of professional top football leagues (England, Germany, Spain, Italy and France), have highly increased in recent decades, as seen in figure 6 (Deloitte, 2016; Pyatunin et al., 2016). 


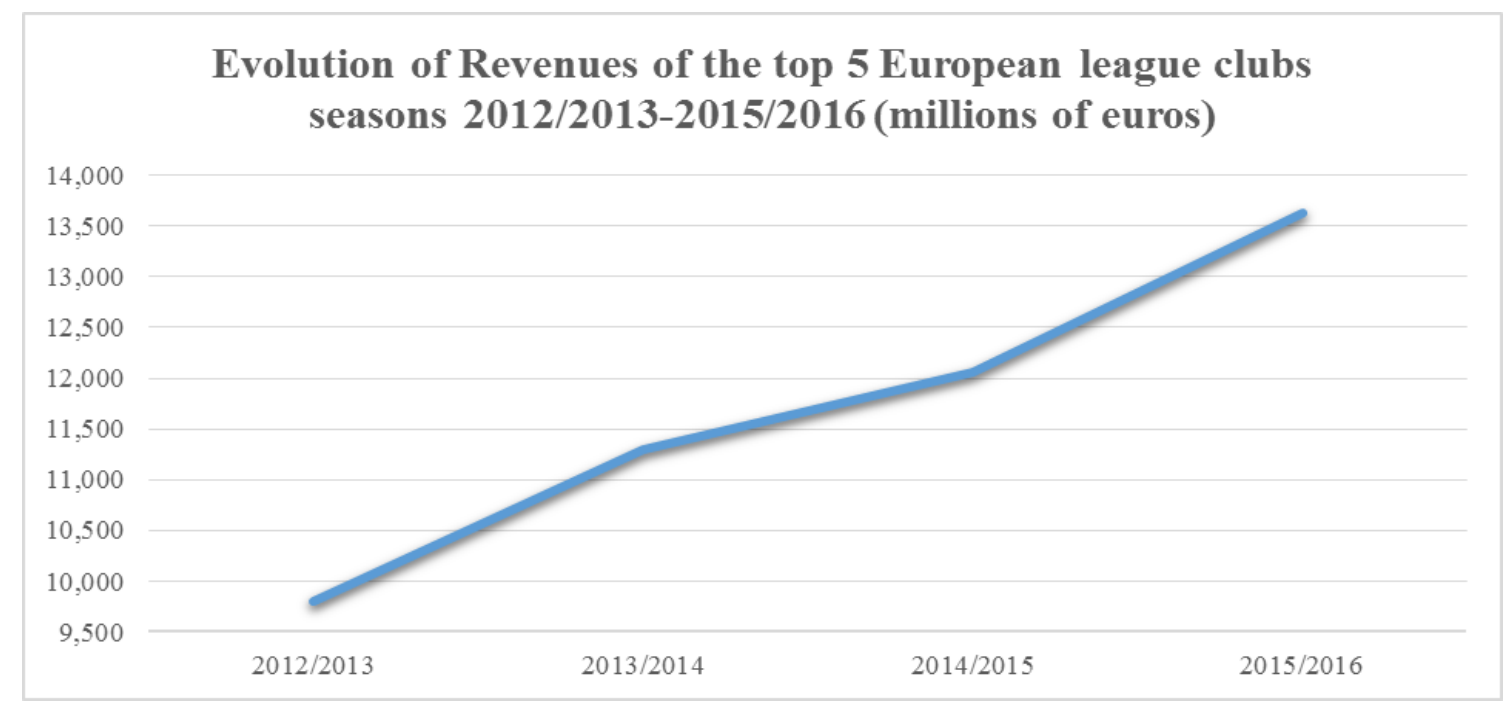

Figure 6. Evolution of revenues of the top 5 European league clubs 2012/2013/2015/2016 in millions of euros (Author's own work based on data of Deloitte, 2016)

Media, sponsors and supporters are three elements that make profit from each other as their symbiotic relationship create the fans' interest (Mullin et al., 2014).

Media is related to TV rights, broadcast rights, sporting awards and publicity, between others (Espitia-Escuer and García-Cebrián, 2010; Calzada, 2012; Mullin et al., 2014; Carmichael et al., 2017). The given amounts depend upon the sponsors' credibility as well as upon the amounts of coverage.

Sponsorships refer to partnerships based on the acquisition of rights for being associated directly to an event or a product. We can distinguish between the main sponsor (logo on the sports uniform), technical (sponsor that promotes the club through the payment of goods and services, as i.e. the medical equipment) or official sponsor (i.e. an official airline partner) (Mullin, 2014). These sponsorships are fundamental for the sport organizations, as they consist in a financial support, although, as shown in figure 7 , the amount depends upon the customer engagement and the fan interest, as well as upon the level of media partnerships (Mullin, 2014).

The term supporters is related to all the revenues that come from ticket sales, seen as one of the fundamental income sources in the professional football (Szymanski, 2006; Mullin, 2014) likewise the merchandising (Mullin, 2014). This fan support is used to attract sponsors and is also determining for media contracts and coverage that will be concluded. 
Obviously, a high potential of financial support also depends on the income that generates the winnings of trophies and the positive performance during the different competitions as well as the sporting recognition.

\section{Investments and expenses}

Furthermore, a high level of financial support merges into the possibility of doing investments that are imperative for contracting the best skilled and talented players that stand out from others, even though this investment generates a huge amount of expenses (Szymanski, 2006; Magaz-Gonzalez et al., 2017). The inputs are various expenses that are related to staff costs, including players', managers' and coaches' salaries as well as the expenses of administration, marketing and the maintenance of facilities, being all of them essential attributes that can lead in proper sequence to sporting success (Guzmán and Morrow, 2007; Szymanski, 2014). Certainly, player salaries comprise the major proportion ( $>50 \%)$ of investment and salaries to pay (Guzmán and Morrow, 2007).

\section{Economic efficiency and survival}

After showing the importance of sporting success of football clubs and the inclusion of elements that should be considered for reaching this first step as financial support, investment and winning competitions, figure 7 points out that those attributes altogether cause economic efficiency that consequently makes football organizations more profitable.

Therefore, it is difficult to be efficient from an economic perspective and generating profits, if sporting aspirations are not met. Literature demonstrates the importance of survival of football clubs as a business unit (Espitia-Escuer and García-Cebrián, 2010). This can be achieved through an increase of income, generated via media (revenues of $\mathrm{TV}$, broadcast rights etc.), fans (ticket sales and merchandising) and sponsors that, in turn, leads to an increase of profits.

\section{Importance of own capital}

Finally, one of the aspects that should be considered, is the owner's equity, the private financial resources, that is increasingly important in the international professional football. It influences positively both, financial efficiency and profitability of football clubs (Dimitropoulus, 2014; Rohde and Breuer, 2016). 
Dimitropoulus (2014) points out that if the focus on owner's equity increases, the leverage level will probably grow. Additionally, the trend of owner's equity is steadily increasing in the professional premier football leagues (Ernst and Young, 2014; Statista, 2017).

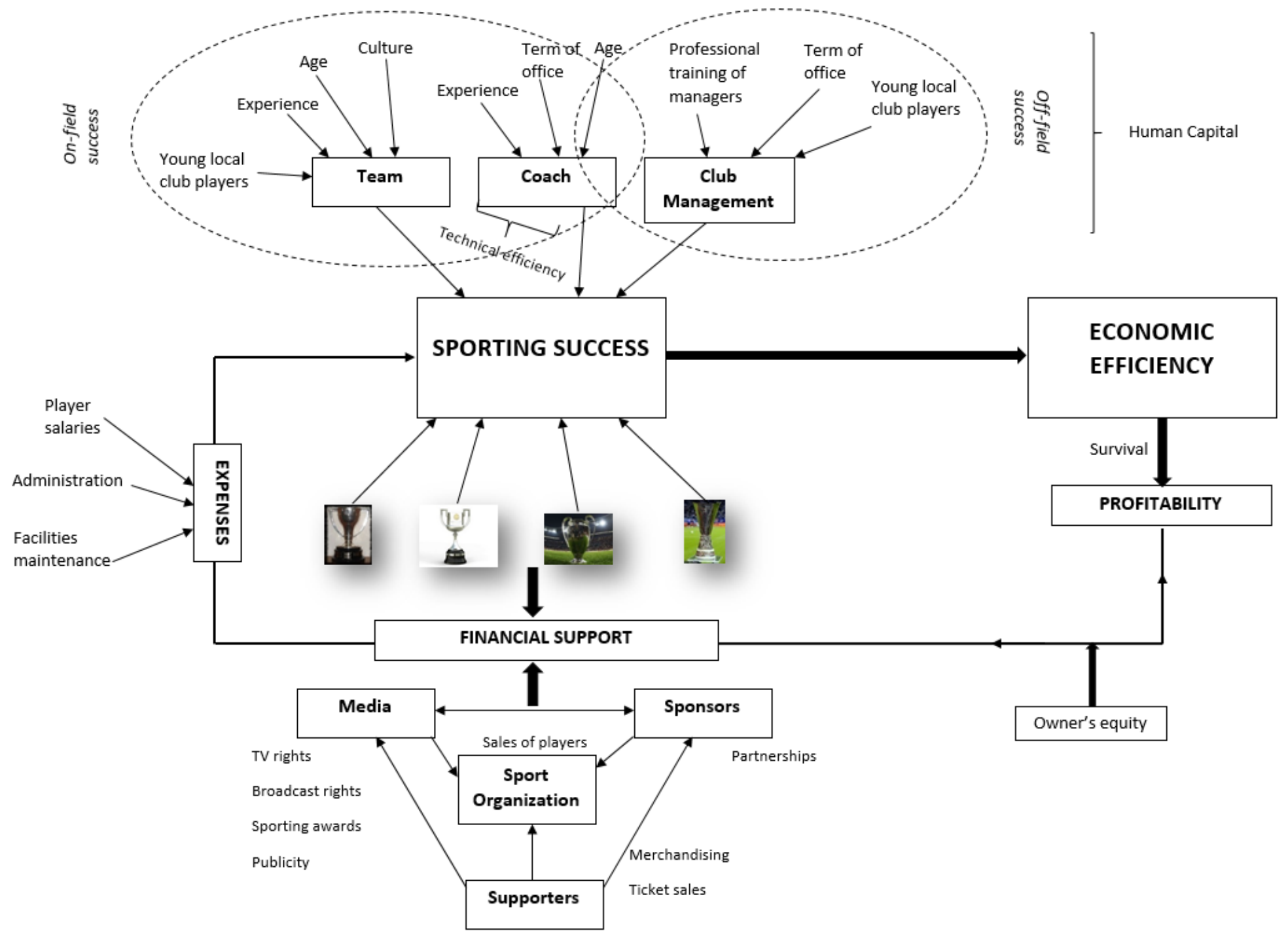

Figure 7. Concept map literature review (Source: Author's own work) 


\section{Conclusions}

This paper has proposed a concept map based on a literature review for managing sporting success and a business units' economic efficiency, analyzing the determinant intermediary factors that should be turned over in the readers' mind.

Nowadays it is important and necessary to understand the economy of the football industry, and to recognize the importance of interaction between concepts that are so essential, as sporting success and economic efficiency.

The academic literature shows that sporting success and economic efficiency are interrelated with each other, especially on a professional level as it is the case of the Europe's premier leagues. It is very difficult to reach sporting success without financial and economic efficiency and vice versa. Therefore, it is essential to manage both concepts constantly, understanding the prerequisites that should be included and which are the attributes that determine a positive sporting and economic outcome.

Considering that the international professional football clubs have been transformed into business units during the last decades, and the football business per se has changed extraordinarily (Murillo, 2012; Deloitte, 2016), it is evident that sporting success is not anymore, the only priority.

Academic literature review demonstrates that the higher the sports level and spectacle is, the more fans will attend the matches (Magaz-González et al., 2017). This, in turn, leads to a higher financial support generated through the fans by ticket sales and merchandising product sales, but also as a result of the enormous increase of media revenues during the last years through TV and broadcast rights, between others, likewise owing to the sponsorships' involvement that is essential for the financial efficiency of a football club (Espitia-Escuer and García-Cebrián, 2010; Calzada, 2012; Bács, 2014; Mullin et al., 2014; Szymanski, 2014; Mullin et al., 2014; Carmichael et al., 2017).

Due to improving financial efficiency and possibilities of higher investments in the best talents (Szymanski, 2006; Guzmán and Morrow, 2007; Szymanski, 2014; MagazGonzalez et al., 2017), together with the achievement of winning competitions and human 
capital, that includes the team, coach and the club management (Espitia-Escuer and García-Cebrián, 2004; Wulf and Hungenberg, 2006; Prestana Barros et al., 2009; Murillo, 2012; Espitia-Escuer and García-Cebrián, 2014; Jara et al., 2015; Yasar et al., 2015; Carmichael et al., 2017), sporting success can be achieved.

Sporting, on-field and off-field success (Guzmán and Morrow, 2007; Espitia-Escuer and García-Cebrián, 2010; Carmichael et al., 2017) leads to economic efficiency and consequently to a higher profitability of the football clubs.

As a concluding remark, given the non-existence of any literature study on this topic, it is believed that this paper can give an insight to managers, practitioners as well as academics into how to manage sporting success and economic efficiency. Furthermore, it emphasizes the attributes that should be paid attention to for accomplishing the main business goals. 


\section{REFERENCES}

Analistas Económicos de Andalucía (AEA) (2002). Deporte y Economía: una cuantificación de la demanda deportiva en Andalucía.

Bács, E. (2014). Challenges to professional football companies and their answer with particular regard to organizational changes. Danube: Law and Economics Review, Vol. 5 (2), pp. 105-125.

Bundesministerium für Wirtschaft und Energie (BMWi) and Bundesinstitut für Sportwissenschaft (BISp) (2015). Wirtschaftsfaktor Fussball, Aktuelle Daten zur Sportwirtschaft.

Calzada, E. (2012). Show me the money!: How to make money from sports marketing. Bloomsbury Publishing Plc.

Carmichael, F., Rossi, G. and Thomas, D. (2017). Production, Efficiency and Corruption in Italian Series A Football, Journal of Sports Economics, Vol. 18 (1), pp. 34-57.

Commission of the European Communities (2007). White paper on sport, European Community.

Deloitte (2016). Annual Review of Football Finance 2016. Sports Business Group, June 2016.

Dimitropoulos, P. (2014). Corporate structure and corporate governance of soccer clubs. European evidence, Management Research Review, Vol. 37 (7), pp. 658-678.

Ernst and Young (2014). Bälle, Tore und Finanzen XI, Enrst and Young Real State GmbH, 2014.

Espitia-Escuer, M. and García-Cebrián, L.I. (2004). Measuring the efficiency of Spanish first-division soccer teams, Journal of Sports Economics, Vol. 5 (4), pp. 329-346.

Espitia-Escuer, M. and García-Cebrián, L.I. (2010). Measurement of the Efficiency of Football Teams in the Champions League, Managerial and Decisions Economics, Vol. 31, pp. 373-386.

Espitia-Escuer, M. and García-Cebrián, L.I. (2014). Comparison of efficiency measures for Spanish first division football teams using data envelopment and stochastic frontier analysis, Atlantic Review of Economics, Vol. 2.

Fort, R. D. (2003). Sports Economics, Person Education LTD.

Gásquez, R. and Royuela, V. (2016). The determinants of international football success: A panel data analysis of the Elo Rating, Social Science Quarterly, Vol. 97 (2), pp. 125 141.

Goddard, J. and Sloane, P. (2014). Handbook on the Economics of Professional Football, Edward Elgar Publishing Limited, USA. 
Guzmán, I. and Morrow, S. (2007). Measuring efficiency and productivity in professional football teams: evidence from the English Premier League, Central European Journal of Operations Research, Vol. 15 (4), pp. 309-328.

Jara, M., Paolini, D. and Tena Horillo, J. (2015). Management efficiency in football: An empirical analysis of two extreme cases, Managerial and Decisions Economics, Vol. 36, pp. 286-298.

KPMG Sports (2015). Socioeconomic impact of professional football in Spain. KPMG Asesores S.L.

LaLiga (2015). Informe económico del fútbol profesional 2015. La Liga de Futbol Profesional.

Magaz-González, A.M., Mallo-Fernández, F. and Fanjul-Suárez, J.L. (2017). Is it profitable to play in Spanish soccer premier league, Revista internacional de medicina y ciencias de la actividad física y el deporte, Vol. 17 (65), pp. 1-26.

Mullin, J., Hardy, S. and Sutton, W.A. (2014). Sport Marketing. $4^{\text {th }}$ edition. USA: Human Kinetics.

Murillo, C. (2012). El FC Barcelona. Claves del modelo Deportivo y de gestión. Revista de Contabilidad y Dirección, Vol. 14, pp. 269-286.

Parks, J.B. and Quarterman, J. (2003). Contemporary Sport Management. $2^{\text {nd }}$ edition. USA: Human Kinetics.

Prestana Barros, C., García-del-Barrio, P. and Leach, S. (2009). Analysing the technical efficiency of the Spanish Football League First Division with a random frontier model, Applied Economics, Vol. 41, pp. 3239-3247.

Pyatunin, A., Vishnyakova, A., Sherstneva, S., Dneprov, S. and Grabozdin, Y. (2016). The Economic Efficiency of European Football Clubs - Data Envelopment Analysis (DEA) Approach, International Journal of Environmental and Science Education, Vol. 11 (15), pp. 7515-7534.

Rohde, M. and Breuer, C. (2016). Europe's Elite Football: Financial Growth, Sporting Success, Transfer Investment, and Private Majority Investors, International Journal of Financial Studies, Vol. 4 (12).

Scopus (2017). www.scopus.com, last access day 4 may, 2017.

Sportcal Global Communications Ltd. (2016). Global Sports Impact Report 2016.

Statista (2015). www.statista.com, last access day 2 may, 2017

Stewart, K. and Jones, J. (2010). Are sports teams multiproduct firms? Empirical Economics, Vol. 39 (2), pp. 487-514. 
Szymanski, S. (2006). The future of Football in Europe. In: Sports Economics after Fity Years: Essays in Honor of Simon Rottenberg, Ediciones de la Universidad de Oviedo, 2006.

Szymanski, S. (2014). Insolvency in English football. In: Handbook on the Economics of Professional Football, Edward Elgar Publishing Limited, USA.

Union of European Football Associations (UEFA) (2017). www.uefa.com, last access day 4 may, 2017.

Web of Science (2017). www.webofknowledge.com, last access day 5 may, 2017.

Weinberg, D. H. (2016). Talent recruitment and firm performance: The business of major league sports, Journal of Sports Economics, Vol. 17 (8), pp. 832-862.

Wulf, T. and Hungenberg, H. (2006). Erfolg von Fussball-Bundesligavereinen: eine empirische Analyse des Beitrags von Mannschaft, Trainer und Sportmanager, Insitut für Unternehmensplanung Internere Bericht.

Yasar, N., Isik, M. and Calisir, F. (2015). Intellectual capital efficiency: The case of football clubs, Procedia - Social and Behavioral Sciences 207, pp. 354-362. 